Archives of Agriculture and Environmental Science

\title{
Effects of organic and inorganic fertilizer combination with insect netting on the production of Indian spinach (Basella alba L.)
}

\author{
M. Mishu Akther ${ }^{1}$, M. Ashraful Islam ${ }^{1^{*}}$ (D), M. Saidee Rahman ${ }^{1}$, M. Habibur Rahman ${ }^{1}$ and Dilip \\ Nandwani ${ }^{2}$ \\ ${ }^{1}$ Department of Horticulture, Bangladesh Agricultural University, Mymensingh 2202, BANGLADESH \\ ${ }^{2}$ Department of Agriculture and Environmental Sciences, College of Agriculture, Tennessee State University, Nashville, TN 37209 , \\ USA \\ "Corresponding author's E-mail: ashrafulmi@bau.edu.bd
}

\section{ARTICLE HISTORY}

Received: 10 June 2019

Revised received: 22 August 2019

Accepted: 26 August 2019

\section{Keywords}

Indian spinach (Basella alba L.)

Inorganic fertilizer

Insect net

Vermicompost

Yield

\section{ABSTRACT}

Best horticulture management has been practiced to reduce the quantity of inorganic fertilizer applications with insect net for higher production of Indian spinach (Basella alba L.). The experiment was conducted at the Horticulture Farm of Bangladesh Agricultural University (BAU), Mymensingh during February to May, 2016. Two factors experiment were conducted on insect nettings (Factor $A$ ): control $\left(N_{0}\right)$, Netting $\left(N_{1}\right)$ and different fertilizers (Factor $B$ ): control $\left(F_{0}\right)$, Vermicompost $10 t /$ ha $\left(F_{1}\right)$, Vermicompost $15 t / h a\left(F_{2}\right), 2 / 3^{\text {rd }}$ of $F_{2}+1 / 3^{\text {rd }}$ of $F_{4}\left(F_{3}\right)$, Inorganic fertilizer $\left(\mathrm{F}_{4}\right)$. Combination of insect net and combined of organic and inorganic fertilizers $\left(\mathrm{N}_{1} \mathrm{~F}_{3}\right)$ gave the significantly higher growth and yield of Indian spinach (B. alba) compared to other treatment combination. The maximum vine length $(77.71 \mathrm{~cm})$, after 45 days after sowing was found in $\mathrm{N}_{1} \mathrm{~F}_{3}$ and it was $72 \%$ higher vine length of Indian spinach compared to control. The highest yield of Indian spinach was $38.67 \mathrm{t} / \mathrm{ha}$ in $\mathrm{N}_{1} \mathrm{~F}_{3}$ which was, $80 \%$ higher yield compared to control ( $7.77 \mathrm{t} / \mathrm{ha})$. The treatment combination of $\mathrm{N}_{1} \mathrm{~F}_{3}$ provided maximum leaf numbers per plant and leaf length of Indian spinach. Organic and inorganic fertilizer application together where reduced amount of inorganic fertilizer technology for crop production can be practiced as a sustainable technology for better growth, yield and quality of a plant, also to improve the soil health and environment in long run.

(C)2019 Agriculture and Environmental Science Academy

Citation of this article: Akther, M.M., Islam, M.A., Rahman, M.S., Rahman, M.H. and Nandwani, D. (2019). Effects of organic and inorganic fertilizer combination with insect netting on the production of Indian spinach (Basella alba L.). Archives of Agriculture and Environmental Science, 4(3): 268-272, https://dx.doi.org/10.26832/24566632.2019.040302

\section{INTRODUCTION}

The use of inorganic fertilizer and chemical pesticide since green revolution has been increased to enhance crop production in agriculture. Benefits on improved yields in crops received, however, unforeseen environmental impacts, human health hazard and resistance to pests and diseases impacted negatively over the years (Chen, 2006; Farjana et al., 2019). Organic fertilizers are environmentally friendly and improve soil health, water-holding capacity, high cation exchange capacity and low bulk density; and they foster a diverse population of beneficial soil microorganisms (Bulluck et al., 2002; Akhter et al., 2019).
Vermicompost contains most of the macro as well as micro nutrients which is beneficial for long-term sustainability and crop productivity (Ansari et al., 2016). Increasing use of organic fertilizers and organic pesticides in crops gaining attention from the farmers due to eco-friendly and safer for human health. Consumers believe that organically produced agricultural products are nutritious, taste good and safer as little or no adverse effect on the environment (Tiziano, 2018).

Insect netting refers covering the crops using mosquito net to provide shade for the crop. Insect netting improved micro -environment, protection from environmental hazards and insect pest damage. Agricultural production is affected due to 
increase in air temperature and intensity of solar radiation due to urbanization. Colour shade can be helpful to improve the microenvironment for plant growth. Several reports are available on the use of shade nets to protect agricultural crops from excessive solar radiation and to improve the thermal climate (Kittas et al., 1999). Vermicompost is a type of organic fertilizer produced by a non-thermophylic process involving interactions between earthworms and micro-organisms leading to bio-oxidation and stabilization of organic material (Edwards and Burrows, 1988; Aira et al., 2000). Applications of vermicompost in combination with chemical fertilizers have been proved effective to enhance growth and yield of different crops like cabbage, tomato and strawberry (Islam et al., 2017a, b; Arancon et al., 2006). Also, Akhter et al. (2019) have shown that 57\% higher yield in okra with combination organic and inorganic fertilizer with insect netting compared to control. This sustainable technology of reduced amount inorganic fertilizer (mixed of organic and inorganic fertilizer) with other management practice like mulch gave the better yield of cabbage and about $63.9 \%$ higher yield of cabbage were found compared to no application of control (Farjana et al., 2019). Mixed fertilizers (combination of organic and inorganic fertilizers) provide nutrients all over growing periods of crops as a result good vegetative growth occur in plant. This combination results in higher yield of crops encourages to reduce the amount of chemical fertilizers application.

Indian spinach is a nutrient rich leafy vegetable grown in the summer season in Bangladesh. It is a fleshy annual, twining much branched herb with alternate ovate leaves. There are two varieties, green and red. The nutritive value of Indian spinach is very high with a good content of minerals, vitamins and substantial amount of fibers (Ghosh and Guha, 1993). Sustainable agriculture is replacing conventional agriculture for crop production in Bangladesh. Reports on higher production of crops through mixed of organic and inorganic fertilizers available (Islam et al., 2017 a, b). This study was conducted to evaluate the production of Indian spinach in mixed fertilizers (organic and inorganic) with insect netting as row covers.

\section{MATERIALS AND METHODS}

\section{Experimental design}

An experiment on Indian spinach was conducted the Horticulture Farm $\left(24^{\circ} 26^{\prime}\right.$ and $24^{\circ} 54^{\prime} \mathrm{N}$ latitude and $90^{\circ} 15^{\prime}$ and $90^{\circ} 30^{\prime}$ E longitude) of Bangladesh Agricultural University, Mymensingh during February to May, 2016 to evaluate the effects of insect netting (blue color mosquito net) and different fertilizers on the growth and yield. Five levels of fertilizer applications viz., $F_{0}$ (control); $F_{1}$ (Vermicompost $10 \mathrm{t} / \mathrm{ha}$ ); $F_{2}$ (Vermicompost $15 \mathrm{t} /$ ha); $F_{3}$ combined fertilizer ( $2 / 3^{\text {rd }}$ of $F_{2}+1 / 3^{\text {rd }}$ of $F_{4}$ treatment), $F_{4}$ (Inorganic fertilizer) and two levels of netting viz., $\mathrm{N}_{0}$ (Control), $\mathrm{N}_{1}$ (Netting). The experiment was laid out in Randomized Complete Block Design (RCBD) with three replications. Inorganic fertilizer $\left(\mathrm{F}_{4}\right)$ was given per hectare $(100 \mathrm{~kg} \mathrm{~N}+22 \mathrm{~kg} \mathrm{P}+70 \mathrm{~kg} \mathrm{~K}$ $+18 \mathrm{~kg} \mathrm{Zn)} \mathrm{according} \mathrm{to} \mathrm{fertilizer} \mathrm{recommendation} \mathrm{guide} \mathrm{(FRG,}$ 2012).

\section{Cultivation practices}

Indian spinach of green color variety seeds were bought from the choto bazar of Mymensingh and it was used as the planting material at the rate $1.170 \mathrm{~kg} / \mathrm{ha}$. Seeds were soaked overnight in a wrapped cotton cloth. Seeds were sown in the field (10 March, 2016) at afternoon in a depth of $1.5 \mathrm{~cm}$ in dibbling method spaced

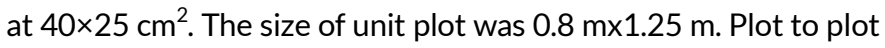
distance was $30 \mathrm{~cm}$ and block to block distance was $50 \mathrm{~cm}$. Seedlings (or transplants) were covered with mosquito net at $4 \mathrm{ft}$ height from the ground level for the convenient of intercultural operation as well as harvesting of Indian spinach. Organic fertilizers (vermicompost), triple superphosphate (TSP) and ZnSO4 were applied before planting. Vermicompost was obtained from Horticulture farm of Bangladesh Agricultural University (BAU). Vermicompost contained $1 \%$ nitrogen. Urea and MoP were applied at three applications at $1^{\text {st }}, 3^{\text {rd }}$ and $5^{\text {th }}$ weeks of seeding, respectively. Weeding and irrigation were done manually. Botanical pesticides, neem extract, ginger and garlic extracts were prepared on farm and sprayed on the plants (except control plots) biweekly to control insect pest and diseases.

\section{Data collection}

Data were collected from each plot (each plot considered as one replication), from which eight plants were selected randomly. Data on the growth parameters were recorded from those respected plants throughout the experimental period. Growth parameters like vine length $(\mathrm{cm})$, leaf number, leaf length $(\mathrm{cm})$, vine diameter $(\mathrm{cm})$, fresh and dry weight of leaves and vines of Indian spinach (B. alba) were recorded. Also, yield per plot were converted to ton per hectare. Fresh leaves and vines (100 g of each samples) were kept in an oven for drying at $65{ }^{\circ} \mathrm{C}$ for 3 days. Percentage dry matter of leaves and vines of Indian spinach were calculated using the following formula:

$\%$ Dry matter $=($ Dry weight $\div$ fresh weight $) \times 100$

\section{Statistical analysis}

Effects of organic and inorganic fertilizers and insect net on growth and yield of Indian spinach were analyzed by analysis of variance (General Linear Model procedure) and Tukey's pair wise comparison test $(P<0.05)$ using Minitab Version 17 (Minitab Inc., State College, PA, USA).

\section{RESULTS AND DISCUSSION}

Consumable part of the Indian spinach is mainly leaves and stems. Vines with leaves were harvested three times above 10$15 \mathrm{~cm}$ from ground level. First harvest was done after 45 days after sowing seeds (DAS). Growth trends data like vine length or plant height, leaves numbers and length, vine diameter of Indian spinach were recorded frequently before the first harvest. After first harvesting, plant produces more branches and influenced yield of Indian spinach. Three harvests were done and collective yield were significantly different among the treatment combinations. Analysis of variance showed that the highest vine length 
and yield Indian spinach were highly significant in the application of organic and inorganic fertilizer with mosquito net treatment $\left(\mathrm{N}_{1} \mathrm{~F}_{3}\right)$ (Figures 1 and 2 ).

The treatment combination $\mathrm{N}_{1} \mathrm{~F}_{3}$ show $72 \%$ and $80 \%$ highest vine length and yield compared to control. The second highest growth and yield of Indian spinach was found from the inorganic fertilizer with net and this was $17 \%$ less production compared to mixed fertilizer with net $\left(\mathrm{N}_{1} \mathrm{~F}_{3}\right)$. In case of Indian spinach crop, trend of plant height and yield is very much inter related. Figures 1 and 2 show that taller plant produced higher yields of Indian spinach, which can be related to the higher length of plant produced higher number of leaves (Table 1). Higher vermicompost application from 10 to $15 \mathrm{t} /$ ha resulted $21 \%$ higher yield. Mixed fertilizer resulted improved production, reduced the amount of inorganic fertilizer and improved soil quality.

Leaf numbers and leaf length of Indian spinach at 25, 35 and 45 DAS were found significantly different and the highest number of leaves and leaf length of Indian spinach were found in $\mathrm{N}_{1} \mathrm{~F}_{3}$ where as the lowest leaf length and leaves number of Indian spinach were found in the control treatment combination

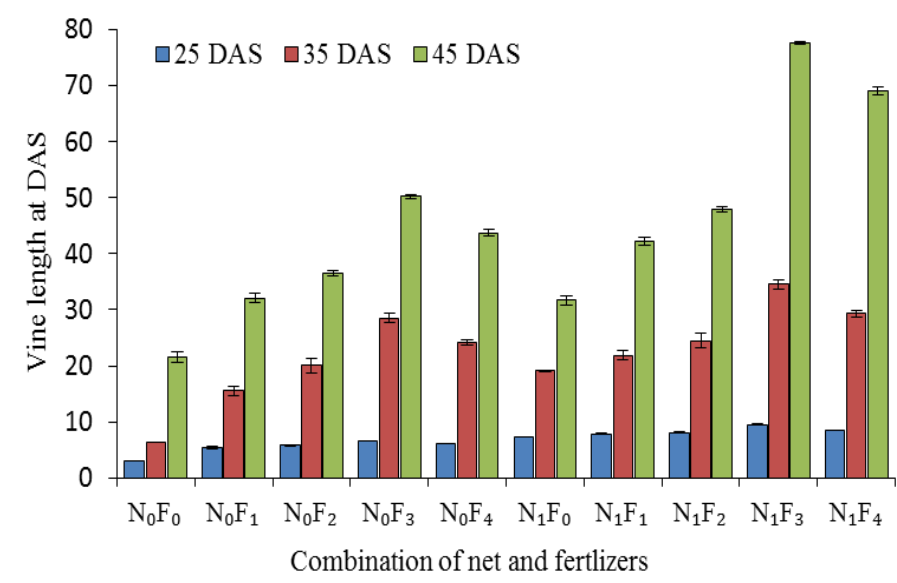

Figure 1. Combined effect of organic, inorganic fertilizers and netting on vine length of Indian spinach. Vertical bars represent \pm SE. (Standard error). $N_{0}=$ Control, $N_{1}=$ Netting; $F_{0}=$ Control (No fertilizer), $F_{1}=$ Vermicompost (10 t/ ha), $F_{2}=$ Vermicompost (15 $\left.t / h a\right), F_{3}=$ Mixed fertilizer $\left(2 / 3^{\text {rd }}\right.$ of $F_{2}+1 / 3^{\text {rd }}$ of $F_{4}$ treatment), $F_{4}=$ Inorganic fertilizer.

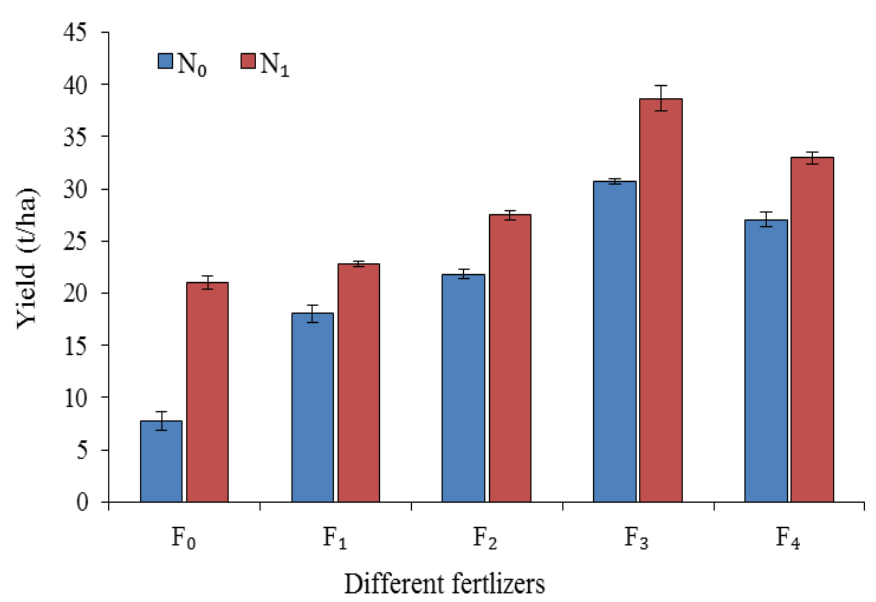

Figure 2. Combined effects of netting and different fertilizers on yield of Indian spinach. Vertical bars represent the $\pm S E$. (Standard error) $N_{0}=$ Control; $N_{1}=$ Netting, $F_{0}=$ Control (No fertilizer); $F_{1}=$ Vermicompost $(10 \mathrm{t}$ ) ha); $F_{2}=$ Vermicompost $(15 t / h a) ; F_{3}=$ Mixed fertilizer $\left(2 / 3^{\text {rd }}\right.$ of $F_{2}+1 / 3^{\text {rd }}$ of $F_{4}$ treatment); $F_{4}=$ Inorganic fertilizer.
(Table 1). The second highest growth was obtained in net with inorganic fertilizer application. Comparing the sole application of inorganic or vermicompost application, improved result was recorded in inorganic fertilizer application. With the higher rate of vermicompost application, growth and yield was increased in Indian spinach. This result is coherence with the result of yield of Indian spinach as leaf number, leaf length and the vine length increased higher yield. In earlier study plants grown under shade (50\%) with nitrogen application showed vigorous growth and yield compared to open field (unshaded condition) in bangladhonia (Eryngium foetidum) (Moniruzzaman et al., 2009). Similarly, Akther et al. (2019) have found that the highest yield of okra was found $57 \%$ higher compared to control which was grown under the netting with the nutrient management combination of organic and inorganic fertilizers. Also, the highest plant height of potato was observed through the combination of vermicompost mixed with 100\% NPKS (chemical fertilizers) was applied to the soil (Alam et al., 2007). On the other hand, tomato leaves were increased by vermicompost applications (Azarmi et al., 2009).

Leaf numbers and leaf length of Indian spinach were increased when the rate of vermicompost application were increased from 10 to 15 ton per hectare. The sole application of inorganic fertilizer produced higher growth and yield compared with sole application of vermicompost in the soil. The higher rate of vermicompost application with the combination of inorganic fertilizer gave the improved results. It is necessary to consider the amount of volume to soil, reduce the amount of inorganic fertilizer which may help to improve the soil quality and ultimately improve the productivity of crop. Considering this, application of organic and inorganic fertilizer combination is suitable for the production, quality of crop and eco-friendly. Best performance of plant growth and yield was found from mixed of organic and inorganic fertilizer with insect net except the vine diameter. Vine diameter was higher in mixed fertilizer without insect net (Table 2).

The best performance on growth and yield findings are in line with study reported on cabbage where the highest growth and yield was higher from the $2 / 3^{\text {rd }}$ organic fertilizer mixed with $1 / 3^{\text {rd }}$ inorganic fertilizer (Islam et al., 2017 a, b). Also, higher yield increased was found in vermicompost applications in lettuce and Amaranthus (Papathanasiou et al., 2012; Uma and Malathi, 2009). The higher yield from the mixed fertilizer provided nutrient supply to crop. Inorganic fertilizers provide rapid release of nutrients and organic fertilizer (vermicompost) supply macro and micronutrients slowly for the plant. Vermicompost application in soil increased their microbial biomass and the dehydrogenase activity. Humic acids and others plant growth influencing substances such as plant hormones produced by microorganisms during vermicomposting and produced after microbial biomass and activity in soil, ultimately increase the growth and yield of crop (Arancon et al., 2008). This finding has potential to reduce applications of inorganic fertilizer to improve soil quality, and sustainable production of crops. Higher production of spinach was obtained in colored 
shade nets such as red, green, black, white along with control (Meena and Vashisth, 2014), which support the result of the present study. Biopesticide was sprayed in the plot of Indian spinach except the control plot. No chemical pesticide was applied in this experiment. It has been found that the visibility of Cercospora leaf spot was very little compared to control. Although, the disease severity data was not considered in this experiment and focus was mainly given to the safe production. Here, the documentation is creating how the reduced amount chemical fertilizer can create opportunity to get higher production which will be safe for the human consumption and sustain the good quality of soil status. In current study mixed or combined fertilizers with insect resulted $26 \%$ higher yield compared to open field (without net). Relative humidity $(\mathrm{RH})$ and temperature were recorded inside and outside of net (data is not shown). No significant variation of $\mathrm{RH}$ and temperature were found from the inside and outside of insect net. Cowdung and integrated nutrient management practices are increasingly use for the higher production of different crops like tomato, brinjal, cabbage and mustard in Bangladesh (Islam et al., 2017a; Solaiman and Rabbani, 2006; Ullah et al., 2008; Haque et al.,
2012). Plant growth promoting rhizobacteria (PGPR) Bacillus spp. which synthesize plant hormones or facilitate the uptake of nutrients from the soil by different direct mechanisms to influence the plant growth, e.g., atmospheric nitrogen $(N)$ fixation, solubilization of phosphorus $(\mathrm{P})$ and synthesis of siderophores for iron sequestration, making nutrients available to plants (Adesemoye et al., 2009; Glick et al., 2007). Combination of organic and inorganic fertilizer including, PGPR, Trichodermaenriched fertilizer influence is observing in different crops where the main focus is to increase the production and to reduce the amount of inorganic fertilizers for improve the quality of crop and soil health in the in long run (Bona et al., 2017; Haque at al., 2012).

Dry matter content (\%) in leaves and stem were higher where the mixed fertilizer $\left(2 / 3^{\text {rd }}\right.$ organic fertilizer with $1 / 3^{\text {rd }}$ inorganic fertilizer) with net was used (Table 2 ) and the second highest dry matter content was found from the inorganic fertilizer with net. Dry matter percentage of leaves is higher compared to vine. It indicates that the higher moisture percentage remains in vine compare to leaves and stems are soft and succulent is suitable for consumption.

Table 1. Combined effects of netting and different fertilizers on leaf numbers per plant and leaf length at different DAS (days after sowing) of Indian spinach.

\begin{tabular}{lcccccc}
\hline \multirow{2}{*}{ Net $\times$ Fertilizer } & \multicolumn{3}{c}{ Leaf numbers per plant } & \multicolumn{3}{c}{ Leaf length (cm) } \\
\cline { 2 - 7 } & 25 DAS & 35 DAS & 45 DAS & 25 DAS & 35 DAS & 45 DAS \\
\hline $\mathrm{N}_{0} \mathrm{~F}_{0}$ & $3.26 \pm 0.08 \mathrm{f}$ & $8.14 \pm 0.09 \mathrm{f}$ & $15.59 \pm 0.13 \mathrm{f}$ & $3.80 \pm 0.07 \mathrm{e}$ & $6.25 \pm 0.09 \mathrm{~g}$ & $8.22 \pm 0.11 \mathrm{f}$ \\
$\mathrm{N}_{0} \mathrm{~F}_{1}$ & $5.80 \pm 0.3 \mathrm{e}$ & $13.07 \pm 0.26 \mathrm{e}$ & $28.36 \pm 0.45 \mathrm{e}$ & $5.67 \pm 0.12 \mathrm{~d}$ & $10.40 \pm 0.1 \mathrm{f}$ & $13.15 \pm 0.2 \mathrm{e}$ \\
$\mathrm{N}_{0} \mathrm{~F}_{2}$ & $6.20 \pm 0.2 \mathrm{~d}$ & $14.25 \pm 0.07 \mathrm{~d}$ & $33.99 \pm 0.56 \mathrm{~d}$ & $6.09 \pm 0.13 \mathrm{c}$ & $12.00 \pm 0.2 \mathrm{~d}$ & $16.34 \pm 0.17 \mathrm{~d}$ \\
$\mathrm{~N}_{0} \mathrm{~F}_{3}$ & $6.92 \pm 0.03 \mathrm{~b}$ & $17.06 \pm 0.42 \mathrm{~b}$ & $47.14 \pm 0.87 \mathrm{~b}$ & $7.07 \pm 0.08 \mathrm{a}$ & $13.44 \pm 0.22 \mathrm{c}$ & $18.54 \pm 0.28 \mathrm{~b}$ \\
$\mathrm{~N}_{0} \mathrm{~F}_{4}$ & $6.62 \pm 0.14 \mathrm{c}$ & $15.37 \pm 0.17 \mathrm{c}$ & $41.96 \pm 0.09 \mathrm{c}$ & $6.37 \pm 0.14 \mathrm{~b}$ & $12.37 \pm 0.19 \mathrm{c}$ & $17.18 \pm 0.13 \mathrm{c}$ \\
$\mathrm{N}_{1} \mathrm{~F}_{0}$ & $6.54 \pm 0.15 \mathrm{~d}$ & $14.51 \pm 0.14 \mathrm{~d}$ & $25.59 \pm 0.38 \mathrm{e}$ & $5.60 \pm 0.04 \mathrm{~d}$ & $11.32 \pm 0.07 \mathrm{e}$ & $13.89 \pm 0.28 \mathrm{e}$ \\
$\mathrm{N}_{1} \mathrm{~F}_{1}$ & $7.16 \pm 0.22 \mathrm{~b}$ & $15.49 \pm 0.77 \mathrm{c}$ & $34.74 \pm 0.58 \mathrm{~d}$ & $6.04 \pm 0.4 \mathrm{c}$ & $12.69 \pm 0.25 \mathrm{c}$ & $16.10 \pm 0.55 \mathrm{~d}$ \\
$\mathrm{~N}_{1} \mathrm{~F}_{2}$ & $7.64 \pm 0.26 \mathrm{~b}$ & $16.89 \pm 0.62 \mathrm{~b}$ & $38.80 \pm 0.85 \mathrm{c}$ & $6.63 \pm 0.19 \mathrm{~b}$ & $14.93 \pm 0.23 \mathrm{~b}$ & $18.23 \pm 0.35 \mathrm{~d}$ \\
$\mathrm{~N}_{1} \mathrm{~F}_{3}$ & $8.77 \pm 0.29 \mathrm{a}$ & $20.48 \pm 0.30 \mathrm{a}$ & $58.00 \pm 1.25 \mathrm{a}$ & $7.88 \pm 0.11 \mathrm{a}$ & $17.24 \pm 0.47 \mathrm{a}$ & $21.49 \pm 0.62 \mathrm{a}$ \\
$\mathrm{N}_{1} \mathrm{~F}_{4}$ & $7.92 \pm 0.20 \mathrm{a}$ & $18.51 \pm 0.54 \mathrm{a}$ & $49.59 \pm 0.67 \mathrm{~b}$ & $6.86 \pm 0.16 \mathrm{~b}$ & $15.70 \pm 0.35 \mathrm{~b}$ & $19.37 \pm 0.33 \mathrm{~b}$ \\
\hline
\end{tabular}

Mean value \pm SE. (Standard error) followed by non-similar letters within a parameter are significantly different at $p<0.05$ according to Tukey's test. DAS = Days after sowing; $N_{0}=$ Control, $N_{1}=$ Netting; $F_{0}=$ Control (No fertilizer), $F_{1}=$ Vermicompost $(10 t / h a), F_{2}=$ Vermicompost $\left(15 t /\right.$ ha), $F_{3}=$ Mixed fertilizer $\left(2 / 3^{\text {rd }}\right.$ of $\mathrm{F}_{2}+1 / 3^{\text {rd }}$ of $\mathrm{F}_{4}$ treatment $), \mathrm{F}_{4}=$ Inorganic fertilizer.

Table 2. Combined effects of netting and different fertilizers on vine diameter and dry matter content in the leaves and vine of Indian spinach.

\begin{tabular}{lccr}
\hline Net $\times$ Fertilizer & Vine diameter at 45 DAS & Dry matter percent in leaves & Dry matter percent in vine \\
\hline $\mathrm{N}_{0} \mathrm{~F}_{0}$ & $0.74 \pm 0.005 \mathrm{f}$ & $6.12 \pm 0.07 \mathrm{f}$ & $3.81 \pm 0.13 \mathrm{~g}$ \\
$\mathrm{~N}_{0} \mathrm{~F}_{1}$ & $0.97 \pm 0.014 \mathrm{e}$ & $12.57 \pm 0.19 \mathrm{e}$ & $5.93 \pm 0.17 \mathrm{f}$ \\
$\mathrm{N}_{0} \mathrm{~F}_{2}$ & $1.31 \pm 0.018 \mathrm{~b}$ & $14.45 \pm 0.23 \mathrm{~d}$ & $6.41 \pm 0.45 \mathrm{e}$ \\
$\mathrm{N}_{0} \mathrm{~F}_{3}$ & $1.47 \pm 0.05 \mathrm{a}$ & $20.40 \pm 0.11 \mathrm{~b}$ & $8.14 \pm 0.57 \mathrm{~b}$ \\
$\mathrm{~N}_{0} \mathrm{~F}_{4}$ & $1.03 \pm 0.035 \mathrm{~d}$ & $15.73 \pm 0.09 \mathrm{~d}$ & $6.85 \pm 0.16 \mathrm{~d}$ \\
$\mathrm{~N}_{1} \mathrm{~F}_{0}$ & $0.65 \pm 0.012 \mathrm{f}$ & $15.45 \pm 0.07 \mathrm{~d}$ & $7.17 \pm 0.23 \mathrm{c}$ \\
$\mathrm{N}_{1} \mathrm{~F}_{1}$ & $0.97 \pm 0.024 \mathrm{e}$ & $17.87 \pm 0.10 \mathrm{c}$ & $7.73 \pm 0.59 \mathrm{~b}$ \\
$\mathrm{~N}_{1} \mathrm{~F}_{2}$ & $1.13 \pm 0.017 \mathrm{c}$ & $19.93 \pm 0.20 \mathrm{~b}$ & $8.18 \pm 0.16 \mathrm{~b}$ \\
$\mathrm{~N}_{1} \mathrm{~F}_{3}$ & $1.22 \pm 0.016 \mathrm{~b}$ & $27.97 \pm 0.11 \mathrm{a}$ & $9.89 \pm 0.45 \mathrm{a}$ \\
$\mathrm{N}_{1} \mathrm{~F}_{4}$ & $1.03 \pm 0.017 \mathrm{~d}$ & $21.60 \pm 0.15 \mathrm{~b}$ & $8.15 \pm 0.43 \mathrm{~b}$ \\
\hline
\end{tabular}

Mean value \pm SE. (Standard error) followed by non-similar letters within a parameter are significantly different at $p<0.05$ according to Tukey's test. DAS = Days after sowing; $N_{0}=$ Control; $N_{1}=$ Netting, $F_{0}=$ Control (No fertilizer); $F_{1}=$ Vermicompost $(10 \mathrm{t} / \mathrm{ha}) ; F_{2}=$ Vermicompost $(15 \mathrm{t} / \mathrm{ha}) ; \mathrm{F}_{3}=\mathrm{Mixed}$ fertilizer $\left(2 / 3^{\text {rd }}\right.$ of $F_{2}+1 / 3^{\text {rd }}$ of $F_{4}$ treatment $) ; F_{4}=$ Inorganic fertilizer. 


\section{Conclusion}

This experiment concludes that the application of combined fertilizer $\left(2 / 3^{\text {rd }}\right.$ of $F_{2}+1 / 3^{\text {rd }}$ of $F_{4}$ treatment) with insect netting showed the highest yield (38.67 t/ha) of Indian spinach (B. alba) than the control treatment combination (7.77 t/ha). Mixed of organic and inorganic fertilizers with net and biopesticide application to the crop showed the potential to enhance yield in Indian spinach and less severity of Cercospora leaf spot of Indian spinach (B. alba). Reduced amount of inorganic fertilizer application practiced to the soil can be a sustainable technology for crop production considering the better growth and yield of crop. Also, this sustainable technology can help to improve the soil quality and environment in a long run.

\section{ACKNOWLEDGEMENTS}

Authors are highly acknowledged to the Department of Horticulture, Bangladesh Agricultural University due to avail the facilities of horticulture farm and the laboratory to conduct the research work.

Conflicts of interest: The authors declare no any conflict of interest regarding publication of this manuscript.

Open Access: This is an open access article published under the terms and conditions of Creative Commons AttributionNonCommercial 4.0 International License which permits noncommercial use, distribution, and reproduction in any medium, provided the original author(s) if the sources are credited.

\section{REFERENCES}

Adesemoye, O.A., Torbert, H.A. and Kloepper, J.W. (2009). Plant growth-promoting rhizobacteria allow reduced application rates of chemical fertilizers. Microbial Ecology, 58: 921-929, https://doi.org/10.1007/s00248-009-9531-y

Aira, M., Monroy, F., Dominguez, J. and Mato, S. (2000). How earthworm density affects microbial biomass and activity in pig manure. European Journal of Soil Biology, 38(1): 7-10, https://doi.org/10.1016/S1164-5563(01)01116-5

Akhter, A., Islam, M.A. and Karim, M.R. (2019). Effects of nutrient management and netting on the growth and yield of okra. Fundamental and Applied Agriculture, 4: 627-631, https://doi.org/10.5455/faa.302744

Alam, M.N., Jahan, M.S., Ali, M.K., Ashraf, M.A. and Islam, M.K. (2007). Effect of vermicompost and chemical fertilizers on growth, yield and yield components of potato in Barind soils of Bangladesh. Journal of Applied Sciences Research, 3(12): 1879-1888.

Ansari, A.A., Jaikishun, S., Islam, M.A., Kuri, S.K., Fiedler, K. and Nandwani, D. (2016). D. Nandwani (ed.), Principles of Vermitechnology in Sustainable Organic Farming with Special Reference to Bangladesh (Chapter 10). Organic Farming for Sustainable Agriculture, Sustainable Development and Biodiversity 9, https://dx.doi.org/10.1007/978-3-319-26803-3_10

Arancon, N.Q., Edwards, C.A., Babenko, A., Cannon, J., Galvis, P. and Metzger, J.D. (2008). Influences of vermicomposts, produced by earthworms and microorganisms from cattle manure, food waste and paper waste, on the germination, growth and flowering of petunias in the greenhouse. Applied Soil Ecology, 39: 91-99, https://doi.org/10.1016/j.apsoil.2007.11.010

Arancon, N.Q.C.A., Edwards, P. and Birerman, P. (2006). Influences of vermicomposts on field strawberries. Part 2: Effect on soil microbiological properties. Bioresource Technology, 97(6): 831-840, https://doi.org/10.1016/j.biortech.2005.04.016
Azarmi, R., Giglou, M.T. and Taleshmikail, R.D. (2009). Influence of vermicompost on soil chemical and physical properties in tomato (Lycopersicum esculentum) field. African Journal of Biotechnology, 7(14): 2397-2401, https://www.ajol.info/index.php/ajb/article/view/59004

Bona, E., Cantamessa, S., Massa, N., Manassero, P., Marsano, F., Copetta, A., Lingua, G., D'Agostino, G., Gamalero, E. and Berta, G. (2017). Arbuscular mycorrhizal fungi and plant growth-promoting pseudomonads improve yield, quality and nutritional value of tomato: A field study. Mycorrhiza, 27: 1-11, https://doi.org/10.1007/s00572-016-0727-y

Bulluck, L.R., Brosius, M., Evanylo, G.K. and Ristain, J.B. (2002). Organic and synthetic fertility amendments influence soil microbial, physical and chemical properties on organic and conventional farms. Applied Soil Ecology, 19:147160, https://doi.org/10.1016/S0929-1393(01)00187-1

Chen, J.H. (2006). The combined use of chemical and organic fertilizers and/or biofertilizer for crop growth and soil fertility. In Proceedings of the International Workshop on Sustained Management of the Soil-Rhizosphere System for Efficient Crop Production and Fertilizer Use, Bangkok, Thailand, 16-20.

Edwards, C.A. and Burrows, I. (1988). The potential of earthworm composts as plant growth media, In Earthworms in Environmental and Waste Management, Neuhauser CA Editor, The Hague, the Netherlands: SPB Academic Publishing, 211-220.

Farjana, S., Islam, M.A. and Haque, T. (2019). Effects of organic and inorganic fertilizers, and mulching on growth and yield of cabbage (Brassica oleracea var. capitata L.). Journal of Horticulture and Postharvest Research, 2(2): 1-10, https://dx.doi.org/10.22077/jhpr.2019.2119.1042

FRG (2012). Fertilizer Recommendation guide. Bangladesh Agricultural Research Council, Farmgate, Dhaka. pp.196.

Ghosh, S. and Guha, A. (1993). Vegetable production in India. Indian Journal of Medical Research, 21: 447.

Glick, B.R., Todorovic, B., Czarny, J., Cheng, Z., Duan, J. and McConkey, B. (2007). Promotion of plant growth by bacterial ACC deaminase. Critical Review of Plant Science, 26: 227-242, https://doi.org/10.1080/07352680701572966

Haque, M.M., Ilias, G.N.M. and Molla, A.H. (2012). Impact of Trichoderma-enriched biofertilizer on the growth and yield of mustard (Brassica rapa L.) and tomato (Solanum lycopersicon Mill.). Agriculturists, 10: 109-119, https://doi.org/10.3329/agric.v10i2.13148

Islam, M.A.,Ferdous, G., Akter, A., Hossain, M.M. and Nandwani, D. (2017a). Effect of organic, inorganic fertilizers and plant spacing on the growth and yield of cabbage. Agriculture, 7: 31, https://dx.doi.org/10.3390/agriculture7040031

Islam, M.A., Islam, M.S., Akter, A., Rahman, H. and Nandwani, D. (2017b). Effect of organic and inorganic fertilizers on soil properties and the growth, yield and quality of tomato in Mymensingh, Bangladesh. Agriculture, 7: 18, https://dx.doi.org/10.3390/agriculture7030018

Kittas, C., Baille, A. and Giaglaras, P. (1999). Influence of covering material and shading on the spectral distribution of light in greenhouses. Journal of Agricultural Engineering Research, 73: 341-351.

Meena, R.K. and Vashisth, A. (2014). Effect of microenvironment under different colour shade nets on biophysical parameters and radiation use efficiency in spinach (Spinacia oleracea L.). Journal of Agricultural Physics, 14: 181-188.

Moniruzzaman, M., Islam, M.S., Hossain, M.M., Hossain, T. and Miah, M.G. (2009). Effects of shade and nitrogen levels on quality bangladhonia production. Bangladesh Journal of Agriculture Resources, 34(2): 205-213.

Papathanasiou, F., Papadopoulos, I., Tsakiris, I. and Tamoutsidis, E. (2012). Vermicompost as a soil supplement to improve growth, yield and quality of lettuce (Lactuca sativa L.). Journal of Food, Agriculture and Environment, 10(2): 677-682.

Solaiman, A.R.M. and Rabbani, M.G. (2006). Effects of NPKS and cow dung on growth and yield of tomato. Bulletin of the Institute of Tropical Agriculture, Kyushu University, 1: 31-37.

Tiziano, G. (2018). Food quality assessment in organic vs. conventional agricultural produce: findings and issues. Applied Soil Ecology, 123: 714-728, https://doi.org/10.1016/j.apsoil.2017.10.014

Ullah, M.S., Islam, M.S., Islam, M.A. and Haque, T. (2008). Effects of organic manures and chemical fertilizers on the yield of brinjal and soil properties. Journal of Bangladesh Agricultural University, 6: 271-276.

Uma, B. and Malathi, M. (2009). Vermicompost as a soil supplement to improve growth and yield of Amaranthus species. Journal of Agricultural and Biological Science, 5(6): 1054-1060, http://www.aensiweb.net/AENSIWEB/rjabs/rjabs/2009/1054-1060.pdf 